\title{
"MISTÄ SE TULEEKIN SE SYYLLISYYS, SE TULEE SIITÄ, ETTÄ ON KOKOVIKA"9
}

LAPSUUDEN TURVATTOMUUDEN TUNNEKOKEMUKSET USKONNOLLISISSA PERHESUHTEISSA

Harriet Tervonen: YTM, lehtori, sosiaalityön jatko-opiskelija, Lapin yliopisto

harriet.tervonen@gmail.com

Janus vol. 29 (2) 2021, 160-175 $\omega$ J a II S

\section{Tiivistelmä}

Artikkelissa tarkastellaan tunteiden merkitystä turvallisuuden rakentumisessa lapsuuden tunnekokemuksissa. Artikkeli jatkaa tutkimuskeskusteluja, joissa lapsuuden kokemuksia ja lasten paikkaa analysoidaan osana uskonnollisten yhteisöjen käytäntöjä. Aineistoa varten on haastateltu neljä aikuista, jotka ovat viettäneet lapsuutensa uskonnollisissa perhesuhteissa. Aineisto on analysoitu aineistolähtöisellä sisällönanalyysillä, joka kohdentui tunteiden kuvauksiin ja niille annettuihin merkityksiin. Turvallisuutta rapauttavat tunnekokemukset liittyvät perheen sisäisten ja ulkoisten suhteiden eroihin sekä uskonnollisten oppien tuottamiin ristiriitoihin. Tulokset korostavat lapsen kokemuksen kuulemisen merkitystä sekä vuoropuhelua uskonnollisten yhteisöjen kanssa,jotta uskonnon vapauden rinnalla turvataan lapsen oikeuden toteutuminen. Sosiaalityössä tarvitaan ymmärrystä asiakkaiden kokemus- ja merkitysmaailmoista, erityisesti silloin, kun kohteena on lapsen oikeuksien toteutuminen.

\section{JOHDANTO}

Uskonnollisten yhteisöjen käytännöt ja sosiaalisiin suhteisiin liittyvät erityispiirteet ovat olleet viime vuosina mielenkiinnon kohteena politiikkatieteiden (Linjakumpu 2012; 2015), teologian (Ruoho 2015; 2017; Stenlund 2016) sekä sosiaalityön tutkimuksessa (Hurtig 2013). Aiheesta on käyty keskusteluja erilaisiin ihmisoikeuskysymyksiin, kuten seksuaaliseen hyväksikäyttöön, väkivaltaan sekä naisten ja lasten asemaan liittyen (esim. Kouros \& Villa 2011). Tutkimuskeskusteluissa on nostettu esille myös uskonnollisuuteen liittyvä joukkovoima (esim. Hurtig 2013). Positiivisimmillaan se näkyy yhteisöllisyytenä ja negatiivisimmillaan toimijuuden rajoituksina. Tutkijat ovat tuoneet esille myös hengellisen vallan luonteen näyttäytymisen muita vallan muotoja vahvempana ja epämääräisemmin rakentuvana. Se voi merkitä sitä, että ulkopuolisen on vaikea havaita hengellisen vallan vääristymiä ja sisäpuolella olevan sellaista määritellä (esim. Hurtig 2013; Linjakumpu 2015).

Monipuolinen, tieteidenvälistä keskustelua hyödyntävä tieto auttaa tavoittamaan kokemuskirjoa, joka voi tulla vastaan uskonnollisiin yhteisöihin kuuluvien tai kuuluneiden ihmisten kanssa myös sosiaalityön ja sosiaalipalvelujen kohtaamisissa. Sosiaalityössä tarvitaan ymmärrystä asiakkaiden merkitys- ja kokemusmaailmoista, erityisesti silloin kun sosiaalityön kohteena on lapsen oikeuksien toteutuminen. On tärkeää 
tutkia erilaisia kasvuympäristöjä ja niihin liittyviä merkityksiä, jotta tunnistetaan ne kohdat, joihin vaikuttamalla voidaan lisätä lasten turvallisuuden kokemusta ja hyvinvointia. Erityisesti lapsiin liitettynä turvallisuudesta puhutaan huolenpitona ja suojeluna (Vornanen \& Törrönen 2012). Lapsen näkökulman kuuleminen on moraalisesti ja eettisesti tärkeää. Lapsen näkökulma kuuluu lapselle, mutta lapsen edun tulkintaa tekevät aikuiset erilaisissa vuorovaikutustilanteissa. Lapsen edun ja näkökulman ymmärtäminen on haastavaa tilanteissa, joissa vanhempien oikeuksien ja lapsen tunnekokemusten ja tarpeiden välille muodostuu ristiriitaa. Usein uskonto luo turvallisuutta ja antaa tukea, mutta se voi muodostua myös taakaksi ja ahdistusta tuottavaksi tekijäksi (Hackney \& Sanders 2003). Tämä on tärkeää tiedostaa myös perheiden kanssa tehtävässä sosiaalityössä.

Tutkimukseni kohdentuu nyt jo aikuisten henkilöiden lapsuuden kokemuksiin turvallisuuden rakentumisesta erityisesti tunteiden näkökulmasta. Kiinnostukseni keskiössä ovat lapsuuteen sijoittuvat muistot ja niissä erityisesti omanarvontuntoa kuormittavat ja minäkuvaa rapauttavat tunteet. Tarkastelen turvallisuutta rapauttavia tunnekokemuksia henkilökohtaisesti koettujen sekä sosiaalisissa suhteissa opittujen ja jaettujen kokemusten näkökulmasta (Bochner ym. 1997; Hurtig 2013). Olen kiinnostunut erityisesti häpeästä ja syyllisyydestä moraalitunteina sekä pelosta, jotka ovat vahvasti sidoksissa turvallisuuden kokemuksiin (Laitinen 2004; Kettunen 2011; Hurtig 2013). Sosiaalityön työkokemukseni myötä olen tullut kosketetuksi ihmisten erilaisista turvattomuuden kokemuksista.
Niiden joukossa uskonnollisissa perhesuhteissa koettujen oman arvon tunnetta kuormittavien ja minäkuvaa rapauttavien tunteiden syvyys ja vaikutus ihmisen elämänvalintoihin ovat jääneet puhututtamaan minua.

Artikkeli pohjautuu pieneen laadulliseen haastatteluaineistoon. Olen haastatellut neljää aikuista, jotka ovat syntyneet ja viettäneet lapsuutensa perhesuhteissa, joissa vallitsi vahvasti uskonnollinen ilmapiiri. Haastateltavat tarkastelivat lapsuuden tunnekokemuksiaan ajallisesta etäisyydestä, jolloin heidän kerrontansa perspektiivi oli eletyn elämän kokemuksissa (myös Bardy \& Känkänen 2005; Eronen 2012; Hurtig 2013). Tutkimuskysymykset ovat: 1) minkälaisia sisältöjä ja merkityksiä tunteet saavat aikuisten lapsuuden muistoissa turvallisuuden rakentumiseen liittyvässä kerronnassa, sekä 2) millaisia erityispiirteitä uskonnollinen yhteisö tuo tunnekokemusten kerrontaan? Koska olen ollut kiinnostunut erityisesti turvattomuutta tuottavista ilmiöistä ja turvallisuuden rakentumisesta ontologisen epävarmuuden tilanteissa (Giddens 1991), tutkimukseni ei tavoita niitä positiivisia ja tukevia asioita, joita uskonnollisuudella on ollut ihmisille. Haluan painottaa tutkimuseettisistä syistä, että tutkimukseni tavoitteena ei ole patologisoida uskonnollisuutta lapsen kasvuympäristön elementtinä, vaikka kohdennunkin riskitekijöihin. Tunnistan uskonnollisuudessa paljon hyviä ulottuvuuksia. Myös tutkimustulokset kertovat siitä, kuinka uskonnollisuudella voi olla vahva voima tukea ihmisiä vaikeiden elämäntilanteiden keskellä ja auttaa myös lapsuuden traumakokemuksista selviytymisessä (esim. Brewer-Smyth \& Koenig 2014). 
Artikkelin keskiössä olevat kysymykset lapsuuden turvattomuutta aiheuttavista tunnekokemuksista ovat sosiaalityössä huomionarvoisia. Artikkeli jatkaa tutkimuskeskusteluja, joissa lapsuuden kokemuksia ja lasten paikkaa analysoidaan osana uskonnollisten yhteisöjen käytäntöjä (Hurtig 2013; Ruoho 2017). Artikkeli on osa lasten turvattomuuden kokemuksia ja turvallisuuden rakentumista käsittelevää väitöskirjatutkimustani (ks. myös Nikupeteri ym. 2015). Artikkelin tavoitteena on tuoda näkyväksi lapsuuden tunnekokemuksia uskonnollisissa perhesuhteissa, joissa vanhempien hyvää tarkoittavat teot voivat muodostaa ristiriidan turvallisuuden kokemukselle. Hyväksi aiotut teot voivat muuntua yhteiskunnallisella tasolla tarkastellen ihmisoikeusloukkauksiksi ja yksilötason näkökulmasta katsottuna monisyisiksi luottamusta ja hyvinvointia rapauttaviksi kokemuksiksi. (Ks. Hurtig 2013; Linjakumpu 2015; Villa 2013.) Lapsi ei voi valita uskontoaan tai sen ulkopuolelle jäämistä. Tämä herättää kysymään: miten arvioida ja tunnistaa, milloin vanhempien uskonnollisuus on riski lapsen turvallisuuden kokemukselle. Eletyn uskon tutkimus painottaa sitä, että usko toteutuu eri tavoin; usko muovaa ihmistä ja ihminen uskoa. Ihmiset eivät omaksu käsityksiään suoraan ja suodattamatta, vaan ovat aktiivisia valinnoissaan. He tunnustelevat sitä, millaista uskoa, ihmiskäsitystä ja maailmankuvaa haluavat edustaa. Toiset lapsuuttaan muistelevat uskonnollisissa yhteisöissä kasvaneet ovat kuvanneet myös armon, pelastusvarmuuden ja uskon tuovan turvallisuuden tunnetta vahvistavan kokemuksen (McGuire 2008). Positiiviset tunteet eivät uhkaa turvallisuuden tunnetta, eivätkä tule auttamissuhteissa työn kohteeksi kuten turvallisuuden tunnetta uhkaavat kokemukset.

Artikkelini rakentuu seuraavasti: avaan ensin tunteiden merkitystä turvallisuuden rakentumisessa uskonnollisten yhteisöjen ja perhesuhteiden kontekstissa. Sitten esittelen tutkimuksen toteutuksen. Tulososassa kuvaan haasteltavien lapsuuden muistoja turvattomuutta aiheuttavista tunnekokemuksista uskonnollisissa yhteisöissä. Lopuksi pohdin yhteiskunnan ja yhteisöjen vastuunkannon merkitystä.

TURVALlisuUden JA TUNTEIDEN SIDOKSET USKONNOLLISISSA PERHESUHTEISSA

Lapsen perusluottamus syntyy perheja yhteisösuhteissa. Luottamus on keskeinen osa identiteetin rakentumista, jonka kehittymiselle yksilön varhaiset elinvuodet ovat merkittäviä. Perusluottamuksen tavoitteena on kasvattaa lapselle sosiaalinen mekanismi, joka vahvistaa yksilön pärjäävyyttä. Perusluottamusta vasten lapselle kehittyy ontologinen turvallisuuden kokemus, itsestä suhteessa toisiin. (Giddens 1991; Vornanen ym. 2009.) Giddensin (1991) mukaan ontologinen turvallisuus on jatkuvuuden ja elämänhallinnan vahva merkityksellistäjä ihmisen elämässä. Turvallisuuden tunne syntyy positiivisesta ja vakauttavasta kokemuksesta, jossa vältytään kaaoksen ja ahdistuksen kokemuksilta (esim. Elias 1982). Mitä enemmän lapsen turvallisuuden tunnetta haastetaan, sitä enemmän lapsi tarvitsee yksittäisiä yrityksiä riskeistä selviytymiseen (Giddens 1991; Vornanen ym. 2009). 
Sosiaalityön tutkimuskeskusteluissa tunteita on käsitelty ammattikäytäntöihin liittyvinä (Forsberg 2002) sekä kokemuksellisina ja kerrottuina (Eronen 2012; Forsberg 2018). Yhteiskunnallisesti tunteet sitoutuvat kulttuuriseen järjestykseen. Tunteita ei nähdä vain yksilön sisäisen mielentilan ilmaisuna, vaan osana minuuden, sosiaalisten suhteiden ja yhteisöjen jäsentämistä. (Ronkainen 1999; Forsberg 2018.) Perinteisesti sosiaalityössä on kiinnitetty huomiota suhteissa elämiseen ja tunteiden huomioonottamista on pidetty enemmän psykologian alaan kuuluvana. Jopa lähi- ja perhesuhteisiin kuuluvana tunteisiin on kiinnitetty vähän huomiota. Vaikka tunteiden sosiologia on vakiinnuttanut paikkaansa tunteiden sosiaalista ja kulttuurista paikkaa tarkasteltaessa, on osa yhteiskuntatieteilijöistä sitä mieltä, että tunteisiin kiinnitetään edelleen liian vähän huomiota. (Pirskanen \& Eerola 2018, 8.)

Ihmiselle on luontaista uskoa johonkin abstraktiin toivoa ja armoa ylläpitävään voimaan. Uskonnollisuuteen liitetään vahvasti toivo ja armo. Vaikka kokemuksellinen, eletty uskonnollisuus liittyy yksilöön, se ei ole pelkästään subjektiivista, vaan vaatii konkreettista tukea sosiaalisesta yhteisöstä. Sosiaaliset yhteisöt luovat käytäntöjä, joissa uskonnollinen toiminta ilmenee. (McGuire 2008, 12-15.) Tutkimuksissa on esitetty uskonnollisuuteen liittyvinä, hyvinvointia edistävinä kaksi tekijää: uskonnollisuuden sosiaaliset resurssit, joissa yksilön uskonnollinen tunnustus vahvistetaan ja otetaan vastaan sekä uskonnon kognitiiviset resurssit, joissa yksilö kokee itsensä yhteisölliseksi ja merkitykselliseksi (Van Cappellen ym. 2016, 486).
Ihmisyyttä syvältä koskevat alueet ovat seksuaalisuus ja hengellinen elämä ja siksi ihminen on haavoittuvimmillaan niissä (Kettunen 2011; Hurtig 2013). Uskonnollisiin yhteisöihin liittyy paradoksaalisuutta, sillä hyvän tuottamiseksi tarkoitetut sanat ja teot voivat tuottaa myös päinvastaisia seurauksia. Uskonnolliset yhteisöt tarjoavat sosiaalista turvaa, mutta usein myös tiivistä kontrollia. Syyllistäminen voi tapahtua ulkoapäin auktoriteettien ja opetusten sivutuotteena (esim. Linjakumpu 2012; 2015). Jos yhteisön uskotaan olevan täydellinen yleisissä käsityksissä, jää syyllisyys epätäydellisyydestä yksilön vastuulle. Yksilön sisäisen syyllisyyden taustalla on omantunnon muokkaaminen yhteisön omantunnon mukaiseksi, mikä voi luoda yksilölle epätäydellisyyden, huonommuuden ja riittämättömyyden tunteita sekä suhteessa Jumalaan että yhteisöön. (Hurtig 2013; Villa 2013.) Siten uskonnollisuuteen liittyvä häpeä on sekä yksilöllistä että yhteisöllistä. Yksilöön kohdistuva häpeä uhkaa ihmisten välisiä suhteita, josta voidaan käyttää termiä sosiaaliseen kontrolliin perustuva häpeä (Scheff 2000). Yhteisöllisellä häpeällä tuotetaan riittämättömyyden tunnetta sosiaalisessa hierarkiassa alempiarvoiselle. Sillä voidaan tavoitella myös yhteisöllistä kuuliaisuutta, protestien ehkäisemistä. (Kettunen 2011, 192-193.)

Perheensisäisissä kiintymyssuhteissa syntyneet häpeäkokemukset voivat usein olla laaja-alaisia ja pysyviä kokemuksia itsestä epäonnistujana, viallisena olentona, joka ei ansaitse rakkautta tai oikeutta olla olemassa (Laitinen 2004; Hurtig 2013). Häpeä syntyy tilanteissa ja suhteissa, joissa yksilö kokee perustavanlaatuista epäonnistumis- 
ta vastavuoroisen yhteyden luomisessa suhteessa toiseen ihmiseen, varhaisimmillaan suhteessa äitiin/huolenpitäjään. Voimakkaassa häpeäkokemuksessa eläminen aiheuttaa inhimillistä kärsimystä. Häpeän aktivoituminen häiritsee sekä sisäistä että ulkoista yhteyttä, vaikeuttaa tietoista läsnäoloa, reflektiivistä toimintaa ja empatiakykyisyyttä. Häpeä ylläpitää pelkoa läheisyyttä kohtaan ja vaikeuttaa avun vastaanottamista. Häpeän liennyttäminen voi puolestaan auttaa avun vastaanottamista. (Esim. Nathanson $1987 ; 1994$.

Syyllisyys on häpeästä kumpuava tunne, joka liittyy ihmisen toimintaan tai toimintaa edeltävään ajatteluun (esim. Laitinen 2004; Hurtig 2013). Uskonnolliset opetukset voivat luoda kuvan kaikkinäkevästä Jumalasta. Mikäli opetuksissa korostuu Jumalan ankaruus, tekee se syyllisyyden tunnekokemuksesta erityisen haastavan. Ihmisen on vaikea hallita täydellisesti ajatuksiaan, ja erityisesti lapsen tai nuoren on vaikea erottaa mielikuvitustaan todellisuudesta, mikä voi edesauttaa lasta syyllistämään itseään pelkästään ajatusten perusteella. (Ruoho 2017.)

Pelko perustunteena on elämää suojeleva, se varoittaa vaaratilanteista. Turvallisuutta rapauttavana tunteena pelkoon liittyy ahdistusta, jolloin pelon kohteen nimeäminen vaikeutuu. Pelkoon liittyvä ahdistus saattaa muodostua selittämättömäksi tunteeksi, joka valtaa ihmisen olemuksen. Pelkoon liittyvään ahdistuksen tunteeseen voi sisältyä erilaisia kehon ja mielen lamaannuttavia kokemuksia. (Marks 2007; Ruoho 2017, 36.)
Häpeä, syyllisyys ja pelko voivat kietoutua tiukkaan kudelmaan, mikä estää ja häiritsee lapsen turvallisuuden rakentumista. Ontologinen häpeä liittyy omaan itseen, kokemukseen arvottomuudesta (Giddens 1991). Häpeän kokemukseen liittyvä syyllisyys puolestaan on yhteydessä tekoihin tai tekoihin liittyviin ajatuksiin. Pelko luottamusta rapauttavana tunteena on ahdistusta aiheuttava Ahdistus voi muodostua kokonaisvaltaiseksi, ihmisen olemassaoloa määrittäväksi kokemukseksi. (Ks. Laitinen 2004; Kettunen 2011; Ruoho 2017.)

\section{TUTKIMUKSEN TOTEUTUS}

Metodologiset sitoumukseni kiinnittyvät sosiaalityön sensitiivisten kohdeilmiöiden tutkimiseen. Monet sosiaalityön tutkimusaiheet liittyvät ihmisenä olemisen arkaluonteisuuteen ja haavoittuvuuteen. Ne kohdentuvat yksilöön ja suhteissa elämiseen sekä niitä tuottaviin ja ylläpitäviin ympäristöihin (Rauhala \& Virokannas 2011; Hurtig 2013; Kiuru 2015; Nikupeteri 2016). Hengellisen kokemisen ja uskonnollisiin yhteisöihin liittyvä ihmisoikeuksien kanssa ristiriidassa olevan toiminnan tutkiminen vaatii sensitiivistä otetta, tutkijana tulee olla tietoinen valintojen seurauksista, siitä minkälaisen kuvan ilmiöstä antaa.

\section{Aineiston keruu}

Olen kerännyt tutkimusaineiston vuosien 2016 ja 2017 aikana. Etsin tutkimuspyynnöllä henkilöitä, joilla oli ollut turvattomuuden tunnekokemuksia uskonnollisissa perhesuhteissa. Haastateltavien taustat ovat erilaisissa uskonnollisissa yhteisöissä. Ratkaisulla pyrin 
välttämään jonkin tietyn uskonnollisen yhteisön leimaamista. Tutkimukseeni osallistui kolme naista ja yksi mies, jotka ovat syntyneet ja viettäneet lapsuutensa uskonnollisissa perheympäristöissä. Tutkittavien lapsuusaika sijoittui 60- ja 80 -lukujen välille. Kaksi heistä on elänyt lapsuutensa lestadiolaisuuteen kuuluvan herätysliikkeen vaikutuksessa. Yksi haastateltava kertoo äidin olleen peruskristitty, joka oli saanut hengelliseen herätykseensä vahvasti vaikutteita lestadiolaisilta saarnamiehiltä. Neljäs haastateltava on nuorena aikuisena irtaantunut Jehovan todistajista.

Aineiston keruussa olen käyttänyt teemahaastattelua (Tuomi \& Sarajärvi 2009). Teemahaastattelussa teemoina olivat lapsuuden turvallisuutta rapauttavat kokemukset uskonnollisen perhesysteemin ja yhteisön vaikutuksessa. Yhden naisista haastattelin ensin teemahaastattelun avulla puhelimen välityksellä. Myöhemmin järjestin uuden haastattelutapaamisen, johon osallistui lisäksi toinen nainen. Haastattelun syvä luonne tuli esille siinä, miten ensimmäisen haastattelun teemat saivat tällä kerralla syvemmän merkityksen ja vahvistuivat toisen haastateltavan tuodessa niihin lapsuudestaan oman samankaltaisen muiston. Haastattelussa naisten kerronta eteni ketjumaisesti, jossa toinen aloitti muiston sanoittamisen, johon toinen liittyi samankaltaisella tunnekokemuksella, jolloin heidän samankaltainen kokemuksellinen muistonsa sai vahvemman sävyn ja merkityksen. Liki kolmen tunnin mittaisen haastattelun aikana haastateltavat palasivat yhä uudestaan joihinkin teemoihin ja niihin liittyviin tunnekokemuksiin, tuoden niihin aina lisää kerrostumaa.
Aineistossa mukana olevan miehen haastattelin samoin ensin teemahaastattelun avulla. Teemahaastattelun aikana haastateltavan kerronta oli tunnustelevaa ja käynnisti haastateltavan kertoman mukaan tunnekokemuksen lapsuuden muistojen palauduttua aktiiviseen ajatteluun. Ensimmäisen haastattelun tallenne oli 30 minuutin mittainen. Toinen haastattelutilanne oli kestoltaan 60 minuuttia. Kolmannen naisen haastattelun toteutin yksittäisenä teemahaastatteluna. Haastattelu kesti 60 minuuttia. Myöhemmin haastateltava lähetti vielä aiheeseen liittyvän kirjoituksen sekä linkin yksityiseen, aihetta käsittelevään blogikirjoitukseen.

Kaikkien neljän haastateltavan kerronnassa korostui turvallisuuden ja turvattomuuden kokemukseen liittyvän haavoittuvuuden lisääntyminen, joka nousi esille tunnekuvauksina. Aineistosta nousi korostuneesti esille häpeän, syyllisyyden ja pelon tunteet ja näistä muodostin aineiston analyysin kulmakivet. Kaikkien neljän haastatellun lapsuuteen liittyy yhteisenä tekijänä se, että vanhemmista toinen on ollut vahvasti uskonnollinen ja toinen vähemmän tai ei juuri ollenkaan. Kolmessa neljästä uskonnollisuuden vaalijana on ollut äiti ja yhdessä se on ollut isä. Uskovalle vanhemmalle tyypillistä oli kaikissa tapauksissa voimakas uskonnollinen kontrollin vaatimus, joka on tullut joko opetuksen tai yhteisön paineen tai molempien vaikutuksesta. Haastateltavilla on retrospektinen katse omaan historiaan. Muistelutyön tuloksena syntyneessä aineistossa ajan kuluminen on voinut osaltaan vaikuttaa tapahtumien muistamiseen ja niiden tulkintaan. (Myös Pirskanen 2009.) Yhteistä kaikille haastateltaville oli se, että he 
etsivät ymmärrystä tapahtumiin ja selitystä vanhemman käytökselle tarkastellessaan lapsuuden kokemuksiaan nyt aikuisen silmin. Koska aineiston informantit ovat valikoituneita, myös tutkimuksen tuottama tieto on rajautunutta, eikä se kerro uskonnollisuuden hyvistä ja tukevista puolista.

\section{Aineiston analyysi}

Olen analysoinut haastatteluaineiston aineistolähtöisesti. Luin litteroituja haastatteluita useaan kertaan, jonka jälkeen koodasin aineiston. Häpeä, syyllisyys ja pelko tunteina korostuivat haastateltavien kerronnassa.Vaikka tunteet limittyivät toisiinsa kaikissa kertomuksissa, tunnekokemukset saivat haastateltavien henkilökohtaiseen elämään liittyviä subjektiivisia painotuseroja ja merkityksïa. Etsin aineistosta ensimmäisessä vaiheessa tunnekertomuksia; niihin liittyviä tilanteita, suhteita ja merkityksiä. Toisessa vaiheessa jäsensin teemoja suhteessa uskonnolliseen kasvuympäristöön. Sosiaaliset suhteet, uskonnolliset traditiot ja opit sekä uskonnollisen ja ei-uskonnollisen maailmankatsomuksen kuilu auttamisjärjestelmässä korostuivat aineistossa. Tarkastelin haastateltavien henkilökohtaisesti kokemien ja sosiaalisissa vuorovaikutussuhteissa opittujen ja jaettujen, uskonnolliseen kasvatukseen liittyvien asioiden suhdetta heidän tunnekokemuksiinsa. (Myös Ellis ym. 2000; Hurtig 2013.) Haastateltavien kokemuksissa lapsuuden uskonnolliseen perheyhteyteen liittyvät häpeän ja syyllisyyden tunnekokemukset kiinnittyivät sosiaalisiin suhteisiin, yhteisöllisiin tilanteisiin ja abstrakteihin kysymyksiin. Lopuksi tein tulkitsevaa luentaa suhteessa lapsuuden tunnekokemuksiin turvalli- suutta heikentävistä kokemuksista ja jäsensin tunnekokemukset kolmeen temaattiseen kokonaisuuteen: perhesuhteisiin, uskonnollisiin oppeihin sekä autetuksi tulemiseen.

Käytän tulkintojeni havainnollistajana aineisto-otteita, joita en identifioi tunnistein haastateltavien tunnistettavuuden suojaamiseksi. Olen poistanut otteista tunnistettavia tietoja. Tutkittaessa henkilökohtaisia kokemuksia on hyvä pohtia oikeutusta tutkia ja kirjoittaa toisten kokemuksista ja sitä, voiko tutkimuksella vahingoittaa tutkittavia henkilöitä ja heidän läheisiään. (Myös Granfelt 1998.) Tutkimuksen eettisten periaatteiden mukaisesti tutkimuksen tulee olla oikeudenmukainen, hyödyllinen ja hyvää aikaansaava. Vahingon tai hyvän tuottamisessa on aina kysymys vallankäytöstä, johon vaikuttaa tutkijan päätöksenteko ja määrittelyvalta. Negatiivisella kirjoitustyylillä voi olla leimaava vaikutus tutkittavien edustamaan ryhmään, kun artikkelin ytimessä olevan uskonnollisen yhteisön ulkoisen hyvän, ihmisyyttä ja oikeaa määrittävien arvojen sekä lapsen tunnekokemusten ja tarpeiden välistä ristiriitaa nostetaan esiin turvattomuutta rapauttavilla tunnekokemuksilla. Vaikka tutkimuksen tavoite on hyvää tuottava, ei se poista vallan epätasaisuutta; lähtökohtaisesti tutkijalla on aina suurempi valta kuin tutkimukseen osallistuvilla. Tutkimuksen tekemisen tärkeä eettinen haaste onkin, miten tutkija tuo näkyväksi tutkimuksen sitoumukset ja arvot. Tutkimuksen eettisenä vaatimuksena on, ettei tutkija jää kiinni omiin henkilökohtaisiin arvoihin ja moraalisiin kysymyksiin (Kuula 2006; Laitinen \& Uusitalo 2007). Olen tutkijana joutunut punnitsemaan tutkittavaan ilmiöön 
liittyviä selitysmalleja ja tulkintoja ja tarkastelemaan niiden suhdetta empiirisiin havaintoihini sekä pohtimaan omia tunnekokemuksia ja uskomuksia uskonnollisuudesta.

\section{Perheen sisäiset ja ulkoiset suhteet OSANA USKONNOLLISIA YHTEISÖJÄ}

Haastateltavat kertoivat ristiriitaisista tunnekokemuksista lapsuuden perheen sisäisissä suhteissa. Heidän kokemuksissaan lähisuhteet kasvattajiin määrittyivät ehdollistetun rakkauden ja turvan lähteenä, jossa uskonnollisuuden traditiot ja opit loivat suodattimen konkreettisen ja abstraktin välille. Lapsen suhde vanhempaan suodattui abstraktin, lapselle jäsentymättömän tekijän kautta. Perheen ja kasvattajan uskonnollisen näkemyksen mukaan, abstrakti suodatin oli joko Jumala tai demoni. Haastateltavat tarkastelivat lapsuuden lähisuhteitaan uskonnollisuuteen ja uskonnolliseen yhteisöön liitettyjen kriteeristöjen ja uskomusten läpi. Lapsina heidän mielessään kasvoi huoli siitä, että vanhemman rakkaus ja turva riippuvat heidän kyvyistään täyttää abstrakteja kriteeristöjä. Haastateltava kuvaa, miten hän herkistyi tarkkailemaan vanhemman nonverbaalisesta viestinnästä merkkejä siitä, oliko hän täyttänyt kriteerit.Vanhemman katse tai huokaus saattoi olla lapselle hylkäämisen merkki, josta lapsi koki itsensä vialliseksi ja riittämättömäksi sekä vanhemmalle että Jumalalle. Arvottomuuden kokemus voi heijastua lapsen mielessä oikeudettomuutena vanhempien rakkauteen ja turvaan.

Mistä se tuleekin se syyllisyys, se tulee siitä, että on kokovika. Lapsi ei pysty täyttä- mään niitä uskovaisen ihmisen kriteereitä. Sen tietää niistä vanhemman huokauksista. Vanhempi huokaisee, kääntää selkänsä ja tiskaa, ja kyyneleet valuu tiskiveteen. Ja se ei ole vain vanhemman suru vaan se on myös Jumalan suru, ettei ole hyvä lapsi. Ei ole riittävä vanhemmalle eikä Jumalalle.

Häpeän tuottaminen vanhemmille ilmeni kaikkien haastateltavien kerronnassa vahvana oman arvon tunnetta mitätöivänä asiana. Arvottomuuden tunne siitä, että ei täytä vanhemman odotuksia ja toiveita. Häpeän ja syyllisyyden taakka vaikutti vielä aikuisuudessa haastateltavien itsensä kokemisessa ja osittain myös elämän valinnoissa. Kaikki haastateltavat kertoivat kuulevansa vielä aikuisenakin vanhemman puheen siitä, kuinka maallistuminen heissä näkyy ja miten toivomukset hengellisen kasvatuksen tavoitteista eivät vanhemman mielessä täyttyneet. Vaikka haastateltavat ovat hakeneet ja osin löytäneet selityksïa vanhempiensa käytökselle, saavat vanhempien ajatukset maallistumisesta vielä aikuisenakin aikaan vääränlaisena nähdyksi tulemisen tunteen.

Et jollaki tavalla se semmosella syyllistämisellä ja häpeän kautta niinko, se semmonen halveksunta maailmanmenoa kohtaan. Ja mikä sitten tuli vielä aikuisena, mulla oli jo lapsiaki, ko äiti sano kerran, että kyllä on hirveän surullista nähä semmonen maallistuminen sinussa. Tulkitsen vieläkin kaikissa suhteissa, kaikista merkeistä, olenko riittävä, se tulee suoraan siitä, että olet hyväksytty vain, jos täytät nämä uskovaisen ihmisen kriteerit.

Haastateltavat toivat esille toisten lasten merkitystä sosiaalisen elämän rikastuttajana. Seurakunnan tapahtumiin liittyi muistoja lapsijoukoista, jotka he 
kokivat yhteisöllisyyttä ja turvallisuuden tunnetta vahvistavina. Lasten kokoontumisissa kaikui ilo ja voimakkaan yhteenkuuluvaisuuden tunne, joita haastateltavat muistelivat hyvinä lapsuudenkokemuksina. Samalla suhteet uskonnollisen yhteisön ulkopuolisiin lapsiin muodostivat ristiriidan. Lapsen sosiaalisen elämän, arjen sidosten ja yhteenkuuluvuuden kyseenalaistamista esiintyi kaikkien haastateltavien kerronnassa. Jehovan todistajista irtaantuneen naisen lapsuutta sävytti ehdoton kielto, jonka mukaan hän ei saanut olla tekemisissä ei-uskovien lasten kanssa, mikä rajasi ja esti huomattavasti lapsen toimijuutta kodin ja uskonnollisen yhteisön ulkopuolella. Muiden haastateltavien kerronnassa kanssakäyminen uskonnollisen yhteisön ulkopuolella olevien lasten kanssa oli hämärästi ohjaillen epäsuotavaa. (Myös Hurtig 2013.) Haastateltavien kerronnassa havainnollistui, miten universaali rakkaudellisuus ihmisiä kohtaan muuntui vanhempien mielissä epäilyksi maallistumisen vaikutuksesta omaan lapseen.

Perheensisäiset ja erityisesti lähivanhempaan liittyvät suhteet nousivat kaikkien neljän haastateltavan kerronnassa korostuneesti esille. Lapsen kokemus siitä, että hän ei täyttänyt uskovaisen ihmisen kriteereitä, syntyi heidän perhesuhteissaan. Turvattomuutta tuottavat tunnekokemukset syntyivät suhteista, sanoista, eleistä ja teoista. Perheen ulkopuolisten suhteiden vaikutus lapsen turvallisuuden kokemiseen vaihteli haastateltavilla henkilökohtaisen elämän ja uskonnollisen yhteisön uskonnollisten ideologioiden ja oppien mukaisesti.

\section{USKONNOLLISTEN YHTEISÖJEN OPIT JA NIIDEN SISÄLLÖT TUNNEKOKEMUKSISSA}

Uskonnollisten yhteisöjen oppien ja niiden sisältöjen muisteleminen lapsuuden kokemuksissa saivat kaikkien haastateltavien kerronnassa suuren painoarvon tunnekokemuksissa. Se, mistä lapsi sai ymmärryksen uskonnollisista opeista, vaihteli hieman. Jehovan todistajien yhteisössä ymmärrys opeista tuli suoraan ohjeistuksista, joita lapsille luettiin päivittäin. Kristillisissä perheyhteisöissä kasvaneiden lasten ymmärrykseen opit tulivat Raamatun teksteistä ja seuraamalla yhteisössä ilmeneviä elämäntapoja sekä poimimalla vanhempien puheessa esiintyviä hyväksynnän tai paheksunnan ilmaisuja.

Mistä tiesi, että joku on oikea uskovainen tai mitä saa tehdä. Ei sitä kotona tarvinnu sanoa, se jostaki tuli. Äidin halveksunta maailman menoa kohtaan oli ilmeinen. Kuka oli uskovainen ja kuka epäuskovainen, se selvitettiin jollakin tavalla, elämäntavat sen osoittivat. Kyllähän se turvallisuus tuli karkeasti siitä, että sinä tiesit, että miten eletään. Kyllähän ne oli paalutettuja, kyllä se lapsi tiesi, että kun sinä näissä raameissa pysyt niin kaikki on ok.

Yhteiskunnallisten ja uskonnollisten arvojen ja tavoitteiden ristiriita näkyy haastateltavien kerronnassa. Arjessa läsnä olevien maallisten ja uskonnollisten sosiaalisten normien ristiriitaisuus välittyy lapselle epämääräisenä, turvattomuutta tuottavana tekijänä. Kristillisen kasvatuksen kodeissa rakkaudellinen sallivuus ihmisen heikkouksille näyttäytyi universaalina rakkaudellisuutena, mutta kääntyi perheen sisäisissä suhteissa uskonnollisia kriteeristöjä valvovaan kontrolliin.Vanhemman huoli siitä, että 
lapset kykenevät täyttämään uskonnollisen yhteisön ja uskomusten määrittelemät uskovaisen ihmisen kriteerit, luo lapselle kokemuksen rakkauden ja turvan ehdollisuudesta.

Meilläkin kävi kaiken maailman puliukkoa kotona ja kaikille oltiin hirveän rakkaudellisia ja sallivia, eikä saarnattu niitä uskoon. Mutta sitten kotona, se hirveä huoli, että omat lapset pääsis taivaaseen, se on kaikista tärkein. Ei millään muulla ole mitään merkitystä.

Kahden haastateltavan kerronnassa nousi esille ripittäytymisen ja siihen liittyvän anteeksiannon ristiriitaisuus suhteessa omiin vanhempiin ja oman olemassaolon oikeutukseen. Lapsuuden kokemus anteeksiantamisesta omalle äidille, kun vanhempi on kokenut epäonnistuneensa kasvattajana, luo lapsen mieleen hämmennyksen ja epätietoisuuden tilan. Vanhemman epäonnistumisen tulos on lapsen mielessä lapsi itse. Lapsen olemassaoloon liittyvä anteeksipyytäminen, joka ei liity mihinkään tapahtumaan, asettaa lapsen ikään ja kehitystasoon nähden sopimattomaan rooliin. Anteeksiannon traditioon liittyvä ehdottomuus ja puhumattomuus lisäävät epätietoisuutta ja käsittämättömyyttä lapsen mielessä, mikä murentaa lapsen ontologisen turvallisuuden kokemusta (Giddens 1991).

Kun vanhemmat pytää anteeksi, että on ollut niin huono äiti, ja lapset joutuu saarnaamaan anteeksi äitille. Se on niin hullu tilanne ja nyt se tarkottaa hyvää, sillä ne oikeasti kokee, että he ovat olleet huonoja vanhempia ja haluaa pyytää sitä anteeksi. Mutta se ei liity mihinkään tapahtumaan, niin että siitä voitais keskustella, vaan, että lapsi pannaan aivan yksinäisyyteen siinä, niinku päästämään äiti jostakin hänen syyllisyydestään. Lapsen tehtävä päästää äiti syyllisyydestä.

Niin ja tarkottaahan se, että minä olen epäonnistunut, jos äit kasvattajana on huono. Tuloshan olen minä.

Kaksi haastateltavaa nosti kerronnassaan esille seuroihin liittyvän hurmoksellisuuden, mikä oli aiheuttanut turvattomuutta, pelkoa ja ahdistusta. Aikuisten hallitsemattomat ja ennakoimattomat, hurmokselliset huudot ja liikehdintä tuottivat haastateltaville pelkoa seuroja kohtaan. Hurmoksellisuuteen liittyvä yhteisöllinen voima lisäsi lapsen mielessä pelkoa ja hämmennystä. Lapsen kokemuksessa hurmoksellisuus näyttäytyi hulluutena, jolle taputetaan, koska se oli Jumalasta peräisin olevaa pyhää. Ahdistavuutta lisäsi pelko siitä, että omat vanhemmat käyttäytyisivät hallitsemattomasti.

Niin nehän herkisty ja sitten niillä alko tulla niitä liikutuksia. Se ulina. Se oli aina niinku räppänä auki kirkossa, että minä näin jo melkein viiksen heilunnasta, että nyt tulee ne liikutukset, silloin minä säntäsin ulos. Pelotti, se oli hirveän tuntusta, et ihmisellä menee kontrolli.

Pelottavaahan se oli... että mitä jos omat vanhemmat ottaa tommosen. Silloin olis mennyt tavallaan luottamus kokonaan, että jos omat vanhemmat tulee hulluksi ja vielä semmonen käsittelemätön. Tavallaan hulluus lapsen silmissä, joka sitten on pyhää, sille kun taputettiin, kun se on Jumalasta.

Kaikkien haastateltavien kerronnassa nousi esille uskonnollisuuteen liittyvät pelottelevat opit. Oppi kaikkinäkevästä Jumalasta tai demonista, joka näkee 
pienimmänkin teon tai ajatuksen, loi pelon ilmapiirin ja murensi turvallisuutta. Pelottelevissa opeissa yhdistyivät konkreettiset ja abstraktit asiat. Vaikka haastateltavat olivat lapsina pyrkineet toimimaan siten, että he noudattavat oppeja, erityisen pelottavaa oli ollut se, että kaikkinäkevä Jumala tai demoni näki myös ajatukset. Syyllisyyden ja häpeän kokemusta vääristä ajatuksista lisäsi uskomus suuresta kirjasta, johon kaikki teot ja ajatukset kirjataan. Tekojen ja ajatusten dokumentointi ja niiden julkinen paljastaminen lisäsi nähdyksi tulemisen häpeää ja vääränlaisuuden ajatusta.

Äiti sano, että Jumala näkee kaikki, mitä sää teet ja kirjottaa kirjaan, ja sitten kun sää kuolet, on semmonen iso taivaan kirja, josta luetaan, että mää oon tehny jotaki ilkeyttä. Ja mää ajattelin, että siellä on lista ja, kun mää kuolen, niin sitten ne kaikki tulee julkisiksi, että kaikki saa tietää.

Jumalaa piti miellyttää, ja sitte koko ajan se ajatus, että jumala näkee mun ajatukset, ja mun täytyy olla varovainen, mitä mää ajattelen. Ja samoin demonit näkee kaiken, mitä mää teen, ja ne houkuttelee mua tekemään kaikkee pahaa ja sitte mun täytyy valita mun oma puoli. Varsinkin nää demonit oli tosi pelottavia. Se riippuu ihan perheestä, et jossain perheissä vedotaan Jumalaan ja joissain demoneihin, ja meijän perheessä oli nää demonit. Se on ollu ihan todella haitallista, vieläkin pelkään yöllä kävellä peilin ohi, kun pelkään, et mä nään siellä demonin.

Abstraktit käsitteet taivaasta ja helvetistä toistuivat kaikkien haastateltavien kerronnassa. Taivas ja helvetti olivat sijoittuneet lapsille rinnakkaisina, käsittämättöminä asioina. Helvetin välttämi- nen ja taivaaseen pääseminen riippuivat lapsen olemassa olemisen tavasta. Helvetti-käsitteestä muodostui haastateltavien lapsuuden tunnekokemuksiin ahdistava ja pelottava paikka, johon liittyi lisäksi abstrakti käsite ikuisuudesta, joka ei koskaan pääty. Taivaaseen pääsyn mittana oli uskonnollisen yhteisön määrittelemä taivaskelpoisuuden määre. Lapsen mielessä tuo mitta on lapsi itse; lapsen teot, ajatukset tai niiden puuttuminen. Negatiiviset tunnekokemukset sävyttivät haastateltavien olemassaoloa ja toimijuutta lapsina.

Mää muistan lapsena, että opetettiin, että jos et elä näin, sää joudut helvettiin ja ikuiseen kadotukseen ja sää et koskaan pääse sieltä pois. Mää muistan sen ahdistuksen, kun mää mietin ikuisuutta ja olin ihan varma, että mää joudun helvettiin. Mää en ollu niin täydellinen, että saatoin tehdä pikku virheitä. Mää aattelin, etten oo sitten niin taivaskelpoinen. Ja mää mietin sitten lapsen ahdistuneesti, että ikuisesti jossakin tulessa. Se oli ihan karmean pelottavaa ja ahdistavaa. Ja kun mää yritin äidiltä tingata, etteikö etes jotakin helpotusta, että millon se ikuisuus loppuu, äiti oli tosi jyrkkä, ettei koskaan. Eikä se nähny tilaa mun ahdistukselle.

Aineisto havainnollistaa, että yhteisöjen opit ja niiden sisällöt ovat monisäikeisesti sidoksissa lapsuuden tunnekokemuksiin ja turvattomuuden syntyyn. Haastateltavien kerronnassa havainnollistui häpeän ilmeneminen Jumalasuhteessa siten, että häpäistyn ihmisen on vaikea ottaa vastaan Jumalan anteeksiantamusta ja armoa. Heidän on vaikea kestää syyllisyyttä siitä, että he ovat rikkoneet Jumalan antamia elämänohjeita (myös Kettunen 2011). 
TUNNISTETUKSI JA AUTETUKSI TULEMINEN

Häpeä ja syyllisyys kietoutuvat haastateltavien kokemuksissa toisiinsa. Vaikka häpeä liitetään käsitteellisesti itseen ja syyllisyys toimintaan, niiden erottaminen kokemuksellisesti toisistaan voi olla hankalaa. Se, minkä ihminen on olettanut olevan syyllisyyttä, onkin osoittautunut häpeäksi. Häpeän ja syyllisyyden nivoutunut taakka näyttäytyi kaikkien haastateltavien kerronnassa elämään ja valintoihin vaikuttavana tekijänä.

Syyllisyyteen kasvaminen, vielä aikuisenakin olen hirveän herkkä syyllistymään. Kristillisestä kasvatuksesta on jäänt paljon semmosta, josta on pitäny selvitä ja rakentaa ittensä uudelleen. Siitä on jääny paljon negatiivista, kun se päämäärä ei oo se lapsi, vaan sen taivaaseen pääsy. Pääsee taivaaseen tai ei joudu helvettiin, se on ihan sama asia. Se olis pitäny tehdä paljo hellemmin. Syyllistävästä helvetinpelon istutuksesta on joutunut pääsemään eroon.

Häpeästä ja syyllisyydestä irrottautuminen on vaatinut haastateltavilta lapsuuden kokemusten työstämistä. Yhdenmukaisesti he kertoivat, miten häpeän ja syyllisyyden taakasta on vaikea selvitä yksin. Yksi haastateltava kuvaa, miten hän on aikuisena oivaltanut, että selviytyminen on vaatinut useita kompensoivia kokemuksia ihmisistä, joille hän on riittävä ja arvokas sellaisenaan.

Kaikki haastateltavat toivat esille tunnistetuksi ja autetuksi tulemisen haasteellisuuden. Nyt aikuisina he arvioivat, että olisivat tarvinneet tukea ja apua erilaisiin hyvinvointia ja turvallisuutta kuormittaviin asioihin. Tärkeimpänä haasteena nousi palvelujärjestelmän vaikeus ottaa puheeksi lapsen tilaa, kun taustalla oli uskonnollisuuteen liittyvää käsitteistöä ja syvälle ulottuvia merkityksiä. Perustuslaki takaa jokaiselle uskonnon vapauden, eikä tuota perusoikeutta ole oikeutettua kyseenalaistaa, mikäli se ei riistä lapsen oikeuksia. Uskonnollisuuteen liittyvä käsitteistö ja ymmärrys sitovat perheyhteisöt ja laajemmat yhteisöt erillisyyteen, johon yhteisön ulkopuolisen voi olla haasteellista tarttua. Yhteisen kielen ja ymmärryksen puuttuminen voi osaltaan estää puheeksi ottamista. Palvelujärjestelmässä on vaikeus ymmärtää uskonnollisuuteen liittyviä kriteeristöjä ja uskonnollisessa yhteisössä voi olla vaikeus luottaa siihen, että tulee kuulluksi oikealla tavalla (myös Hurtig 2013).

\section{Palvelujärjestelmässä on vaikea puuttua tai ottaa asiaa puheeksi lapsessa ilmenevää huolta, kun uskovilla ja epäuskovilla ei ole yhteistä ymmärrystä.}

Uskonnollisuuteen liittyvä abstrakti käsitteistö ja kriteeristö yhdistettynä yhteisön muovaamaan ymmärrykseen oikeasta ja väärästä, luo syväluotaavat vaikutukset ihmisenä olemisen ytimeen. Se luo totuuden, josta on haastavaa irrottautua. Haastateltavat kertoivat myös vastaavasti, että uskova auttaja tai viranomainen antoi luottamusta siihen, että tuli oikealla tavalla kuulluksi, ymmärretyksi ja autetuksi.

Sillon ku mää olin terapiassa, niin mulla autto ihan hirveästi, että mää tiesin, että mulla on uskovainen terapentti. Se huonommuuden tunne oli aivan hirveä, mutta siinä auttoi tieto, että on kristillinen terapeutti.

Aineisto havainnollistaa, että lasten avun ja tuen tarpeiden tunnistaminen hyvinvointia ja turvallisuutta kuormittavissa 
asioissa on vaativaa. Uskonnollisen yhteisön ja perheyhteisön muodostama kontrollin verkosto voi osaltaan rajata autetuksi tulemisen mahdollisuuksia, uskonnollisen yhteisön ja palvelujärjestelmän yhteistyötä. Samalla myös jaetun ymmärryksen puuttuminen voi haastaa oikea-aikaisen palveluiden saamista.

\section{JOHTOPÄÄTÖKSET}

Tutkimusaineisto on pieni, mutta tuo esille mielenkiintoisia ja yhdistäviä piirteitä uskonnolliseen kasvuympäristöön liittyvissä kokemuksissa. Tutkimusaineistossa korostuvat lapsuuden muistot, joihin sekoittuu vivahteita ajalliseen viiveen synnyttämästä selityksestä. Haastateltavat pyrkivät aikuisena löytämään selityksiä vanhempien hylkäävälle ja laiminlyövälle käytökselle sekä pohtivat omaa suhdettaan uskonnollisiin kysymyksiin. Seurauksissa kietoutuvat toisiinsa uskonnollisuus, vanhempien persoonalliset ja käyttäytymiseen liittyvät ongelmat. Kokonaisuus on synnyttänyt sen, että näiden lasten tarpeet ovat ohittuneet.

Tulokset osoittavat, että lapsuuden uskonnollisessa kasvatuksessa koetut ontologisen häpeän, syyllisyyden ja pelon tunnekokemukset kiinnittyvät sosiaalisiin suhteisiin, yhteisöllisiin tilanteisiin ja abstrakteihin kysymyksiin. Siten on tärkeää, että myös sosiaalityössä ammattilaisilla olisi tietoa erilaisista uskonnoista ja niiden käytännöistä. Tietoa tarvitaan siitä, miten uskontojen eri puolet voivat tulla erilaisissa ympäristöissä esiin ja miten niitä koetaan. Tärkeää on tunnistaa positiivisia, tukevia tapoja, käytäntöjä ja suhteita sekä sulkevia käytäntöjä, dikotomisia määrittelyjä ja vallan vääristymiä niin sukupuolten kuin sukupolvien välillä. Tällöin ammatillisissa käytännöissä voidaan vahvistaa uskonnon hyviä ulottuvuuksia ja vastaavasti pyrkiä eliminoimaan riskejä ja heikentämään niiden vaikutusta. Tutkimukseni tulokset korostavat lapsen tiedon ja kokemuksen kuuntelemisen merkitystä. Uskonnollisten yhteisöjen oppeihin liittyvä tulkinnanvaraisuus voi luoda lapselle ristiriitaisen kokonaiskäsityksen siitä, minkä kriteeristön mukaan hän itseään arvioi suhteessa vanhempiin, yhteisöön ja abstrakteihin kysymyksiin. Uskonnollisen kriteeristön myötä ehdolliset rakkauden osoitukset rapauttavat lapsen luottamusta riittävyydestään suhteessa lähivanhempaan, yhteisöön ja Jumalaan, eikä yksilölle luontaiselle neuvottelulle ja vastustukselle ole tilaa (Notko \& Sevón 2018, 68). Lapsen kokemus kokovikaisuudesta, siitä ettei ole riittävän hyvä lapsi vanhemmalle eikä Jumalalle, kuvastaa häpeän kokemuksen kokonaisvaltaisuutta. Häpeä ja syyllisyys ovat kokonaisvaltaisia omanarvontunnetta heikentäviä tunteita, joiden tunnistaminen voi olla vaikeaa. On tärkeä tuoda ammatillisiin keskusteluihin entistä enemmän lapsen oman kokemuksen kuulemisen rinnalle tunteiden ja tunnesidosten tunnistaminen. Samalla tärkeäksi muodostuu tunteiden ja tunnesidosten prosessimaisuuden ja muuttumisen tunnistaminen luottamuksen rakentumisessa ja turvallisuuden kokemisen vahvistamisessa.

Tutkittavien lapsuuden turvattomuuden tunnekokemuksiin liittyy sekä konkreettisia muistoja lähisuhteiden suojan pettämisestä että abstrakteja mielikuvia taivaasta ja helvetistä. Näiden negatiivisten tunteiden juuret voivat olla syvällä ja näyttäytyvät vielä 
aikuisuudessakin sisäisenä, kokonaisvaltaisena osana heidän käsitystään itsestään. (Myös Tangney \& Dearing 2002; Hurtig 2013.) Aineistosta nouseva, uskonnollisen yhteisön oppiin liittyvä ripittäytyminen ja sen kautta näkyväksi tuleva anteeksiantaminen voi vääristää lapsen ja aikuisen välisiä suhteita. Ripittäytymiseen liittyvä vanhemman anteeksiannon vaatimus lapselle, asettaa lapsen ikään ja kehitystasoon nähden sopimattomaan rooliin. Anteeksiannon traditioon liittyvä ehdottomuus ja puhumattomuus lisäävät epätietoisuutta ja käsittämättömyyttä lapsen mielessä, mikä murentaa lapsen minäkuvaa ja turvallisuuden kokemusta. Vaikka turvallisuutta rapauttavat tunnekokemukset voivat vaurioittaa tunnesidoksia lähisuhteisiin sekä myös hengelliseen elämään, voivat korvaavat hyväksyvät huolenpitosuhteet myötävaikuttaa tunnesidosten korjaantumiseen, mikä osaltaan voi vaikuttaa myönteisesti turvallisuuden tunnekokemukseen (myös Elias 1985; Smart 2007; Pirskanen \& Kallinen 2018, 241-256). Tutkimustulokset osoittavat, että kun turvallisuutta rapauttavat tunnekokemukset ovat syvällä minuudessa, tarvitaan useita ja toistuvia huolenpitosuhteita luottamuksen uudelleen rakentumiseen.

Lapsuuden turvattomuuden kokemukset tuottavat erilaisia psykososiaalisen avun ja tuen tarpeita. Vaikka uskonnollisissa yhteisöissä ei avun pyytämiselle asetettaisikaan esteitä, voi uskonnolliseen yhteisöön sitoutunut kokea haastavaksi kuvata henkilökohtaiseen elämään liittyviä asioita ammattilaiselle, jonka kykyyn ymmärtää uskonnollisen yhteisön normien ja oppien merkitystä hän ei voi luottaa. Kokemus siitä, että uskonnollisiin oppeihin sitoutunut am- matillinen auttaja ymmärtää parhaiten, toistui aineistossa. Toisaalta myös ammattilaisen vääränlainen sensitiivisyys ottaa puheeksi uskonnollisuuteen liittyviä kysymyksiä voi kapeuttaa ammatillista auttamista. (Myös Hurtig 2013, 256.) Tiedostamalla uskonnollisten yhteisöjen oppeihin ja käytänteisiin liittyviä tekijöitä, voidaan paremmin tunnistaa niitä kiistanalaisia tilanteita, joissa vanhempien oikeuksien ja lapsen tunnekokemusten ja tarpeiden välille muodostuu ristiriitaa.

Haastateltavien lapsuus sijoittuu 60- ja 80-lukujen välille. Uskonnolla on aikaisemmin ollut suomalaisessa yhteiskunnassa ja lapsuuden instituutioissa vahvempi rooli kuin nykyisin. Myös lapsen asema perheissä ja yhteisöissä on vaihdellut eri aikoina, mikä voi osaltaan vaikuttaa lapsen toimijuuteen Lisäksi internetin tarjoama verkosto voi nykyisin avata uudenlaisia vaihtoehtoja tiukan kasvuympäristön ilmapiirille. Maallistumisen trendi on vahvistunut, mutta toisaalta uusia uskontoja syntyy. Uusien uskonnollisten yhdyskuntien lasten moraalikasvatusta koskevista tunnesäännöistä tarvitaan uutta ymmärrystä.

Sosiaalialan ammattikeskusteluissa uskonnollisten yhteisöjen käytänteet eivät ole olleet kauan. Tutkimuksissa eletty usko painottuu eri tavalla. Toiset uskonnollisissa yhteisöissä kasvaneet muistelevat lapsuuttaan armon, pelastusvarmuuden ja uskon tuoman turvallisuuden tunteen ympäröimänä. Toisille uskonnollisen yhteisön hyvän lapsen normit voivat aiheuttaa syvää ristiriitaa ja riittämättömyyden tunnetta, joka voi vaikuttaa lapsen ja vielä aikuisenkin minuuden kokemukseen negatii- 
visesti. Positiiviset tunteet eivät uhkaa turvallisuuden tunnetta, eivätkä tule auttamistyössä työn kohteeksi samalla tavalla kuin turvallisuutta rapauttavat tunnekokemukset. Tämän artikkelin pienestä aineistosta nousi esille lapsuuden kokemus kokovikaisuudesta, riittämättömyydestä hyvän lapsen vaatimuksiin. Jatkotutkimuksen aiheena olisi kiinnostavaa tutkia hyvän lapsen tunnenormeja uskonnollisissa yhteisöissä.

Uskonnollisiin perhesuhteisiin liittyvien turvallisuutta rapauttavien tunnekokemusten syvyys haastaa lisäämään omaa ammatillista ymmärrystä uskonnollisuuden eri puolista lapsuuden kasvuympäristössä. Tarvitaan lisää tutkimuskeskusteluja niin uskonnollisten yhteisöjen lapsen kasvua ja kehitystä myönteisesti tukevista tekijöistä kuin uskonnollisen vallan vääristymistä. Tämän rinnalle tarvitaan ihmisten välistä dialogia sekä vuoropuhelua uskonnollisten yhteisöjen kanssa, jotta turvataan uskonnon vapauden rinnalla lapsen oikeuksien toteutuminen.

\section{Kirjallisuus}

Bardy, Marjatta \& Känkänen, Päivi (2005) Omat ja muiden tarinat ihmisyyttä vaalimassa. Helsinki: Stakes.

Bochner, Arthur P. \& Ellis, Carolyn \& Tillmann-Healy, Lisa M. (1997) Relations as Stories. Teoksessa Steve Duck (toim.) Handbook of Personal Relationships, $2^{\text {nd }}$ ed. New Jersey: John Wiley \& Sons Ltd.

Brewer-Smyth, Kathleen \& Koenig, Harold G. (2014) Could Spirituality and Religion Promote Stress Resilience in Survivors of Childhood Trauma? Issues in Mental Health Nursing 35 (4), 251-256. https://doi.org/10.3109/01612840.201 3.873101
Elias, Norbert (1982) What is Sociology. London: Hutchinson.

Eronen, Tuija (2012) Lastenkoti osana elämäntarinaa. Narratiivinen tutkimus lastenkodissa asuneiden kertomuksista. Acta Universitatis Tamperensis 1713. Tampere: Tampere University Press.

Forsberg, Hannele (2002) Tunteet - sosiaalityötä harjoittelevan häpeä? Aikuiskasvatus 22 (4), 295-305. https://doi. org/10.33336/aik.93437

Forsberg, Hannele (2018) Lasten tunteet, perhesuhteet ja koti. Teoksessa Petteri Eerola \& Henna Pirskanen (toim.) Perhe ja tunteet. Helsinki: Gaudeamus, 31-47.

Giddens, Anthony (1991) Modernity and Self-Identity. Oxford: Polity Press.

Granfelt, Riitta (1998) Kertomuksia naisten kodittomuudesta. Suomalaisen Kirjallisuuden Seuran toimituksia 702. Helsinki: Suomalaisen kirjallisuuden seura.

Hackney, Charles H. \& Sanders, Glenn S. (2003) Religiosity and Mental Health: A Meta-Analysis of Recent Studies. Journal for the Scientific Study of Religion 42 (1), 43-56. https://doi. org/10.1111/1468-5906.t01-1-00160

Hurtig, Johanna (2013) Taivaan taimet. Uskonnollinen yhteisöllisyys ja väkivalta. Tampere:Vastapaino.

Kettunen, Paavo (2011) Kätketty ja vaiettu - suomalainen hengellinen häpeä. Helsinki: Kirjapaja.

Kiuru, Hanna (2015) Tragedian tarinat. Nuoren itsemurhaan päättynyt elämä vanhemman kertomana. Annales Universitatis Turkuensis C 404. Turku:Turun yliopisto.

Kouros, Kristiina \& Villa, Susanna (2011) Iloisen talon kellareissa. Helsinki: Like.

Kuula, Arja (2006) Tutkimusetiikka. Aineistojen hankinta, käyttö ja säilytys. Tampere:Vastapaino.

Laitinen, Merja (2004) Häväistyt ruumiit, rikotut mielet. Tampere:Vastapaino.

Laitinen, Merja \& Uusitalo, Tuula (2007) Sensitiivisen haastattelututkimuksen eettiset haasteet. Janus 15 (4), 316-332.

Linjakumpu, Aini (2012) Haavoittunut yhteisö: Hoitokokoukset vanhoillislestadiolaisuudessa. Tampere:Vastapaino.

Linjakumpu, Aini (2015) Uskonnon varjot. Hengellinen väkivalta kristillisissä yhteisöissä. Tampere:Vastapaino. 
Marks, Isaac M (2007) Pelko - osa elämää. Suom. Anna Vihra. Espoo: Prometheus Kustannus Oy.

McGuire, Meredith B (2008) Lived Religion: Faith and Practice in Everyday Life. Oxford: University Press.

Nathanson, Donald L. (1994) Shame and Pride: Affect, sex, and the Birth of the Self. New York and London: W. W. Norton \& Company.

Nathanson, Donald L (1987) The Many faces on Shame. New York: Guilford Press.

Nikupeteri, Anna \& Tervonen, Harriet \& Laitinen, Merja (2015): Eroded, Lost or Reconstructed? Security in Finnish Children's Experiences of Post-Separation Stalking. Child Abuse Review 24 (4). https://doi.org/10.1002/car.2411

Nikupeteri, Anna (2016) Vainottuna. Eron jälkeisen vainon tunnistaminen ja uhrien kohtaaminen. Acta Universitatis Lapponiensis 336. Rovaniemi: Lapin yliopistokustannus.

Notko, Marianne \& Sevón, Eija (2018) Konfliktit lasten perhesuhteissa. Teoksessa Petteri Eerola \& Henna Pirskanen (toim.) Perhe ja tunteet. Helsinki: Gaudeamus, 67-87.

Pirskanen, Henna (2009) "Was your father a problem drinker?" Challenges of life story interviewing in researching adult sons of problem drinking fathers. Journal of Comparative Social Work 4 (1), 1-17. https://doi.org/10.31265/jcsw.v4i1.47

Pirskanen, Henna \& Eerola, Petteri (2018). Teoksessa Petteri Eerola \& Henna Pirskanen (toim.) Perhe ja tunteet. Helsinki: Gaudeamus, 8.

Pirskanen, Henna \& Kallinen, Kati (2018) Jännitteisten vanhempi-lapsisuhteiden tunnesidokset. Teoksessa Petteri Eerola \& Henna Pirskanen (toim.) Perhe ja tunteet. Helsinki: Gaudeamus, 241-257.

Rauhala, Pirkko-Liisa \& Virokannas, Elina (2011) Sosiaalityön tutkimuksen etiikka, opettaminen ja tietoarvo. Teoksessa Aini Pehkonen \& Marja Väänänen-Fomin (toim.) Sosiaalityön arvot ja etiikka. Jyväskylä: PS-kustannus, 235-255.
Ronkainen, Suvi (1999) Subjektius, häpeä ja syyllisyys parisuhdeväkivallan elementtinä. Teoksessa Sari Näre (toim.) Tunteiden sosiologiaa. Hämeenlinna: Karisto Oy, 131-154.

Ruoho, Aila (2015) Toisenlainen totuus jehovantodistajuudesta. Jyväskylä: Atena.

Ruoho, Aila (2017) Pyhät, pahat ja pelokkaat. Pelko ja itsetuhoisuus hengellisissä yhteisöissä. Jyväskylä: Atena.

Scheff, Thomas J. (2000) Shame and the Social Bond: A Sociological Theory. Sociological Theory-18 (1), 84-99. https:// doi.org/10.1111/0735-2751.00089

Smart, Carol (2007) Personal Life. New directions in sociological thinking. Malden: Polity Press.

Stenlund, Mari (2016) "Hengellinen väkivalta uskonnonvapautta ja mielenterveyttä koskevien oikeuksien haasteena". Teoksessa Maarit Hytönen, Kimmo Ketola, Veli-Matti Salminen, Jussi Sohlberg \& Leena Sorsa (toim.) Erilaisista yhteisöistä elävä kirkko. Kuopio: Kirkon tutkimuskeskus, 213-234.

Tangney, June Price \& Dearing, Ronda L. (2002) Shame and Guilty. New York: Guilford Press.

Tuomi, Jouni \& Sarajärvi, Anneli (2009) Laadullinen tutkimus ja sisällönanalyysi. Helsinki:Tammi.

Van Cappellen, Patty \& Toth-Gauthier, Maria \& Saroglou,Vassilis \& Fredrickson, Barbara L. (2016) Religion and well-being: The mediating role of positive emotions. Journal of Happiness Studies 17 (2), 485-505. https://doi.org/10.1007/ s10902-014-9605-5

Villa, Janne (2013) Hengellinen väkivalta. Helsinki: Kirjapaja

Vornanen, Riitta \& Törrönen, Maritta \& Niemelä, Pauli (2009) Insecurity of young people: The meaning of insecurity as defined by 13-17-year-old Finns. Young 17 (4), 399-419. https://doi. org/10.1177/110330880901700404 